International Journal of English Literature and Social Sciences
Vol-6, Issue-1; Jan-Feb, 2021
Journal Home Page Available: https://ijeab.com/
Journal DOI: $10.22161 /$ ijels

\title{
Comparative Literature: Its Emergence, Challenges and Suggested Developments
}

\author{
Anandita Sharma
}

Assistant Professor, Sanatan Dharam College, Ambala Cantt \& PhD. Research Scholar, Department of English and Cultural Studies, Panjab University, Chandigarh, India

Received: 25 Oct 2020; Received in revised form: 28 Jan 2021; Accepted: 15 Feb 2021; Available online: 26 Feb 2021

(C2021 The Author(s). Published by Infogain Publication. This is an open access article under the CC BY license

(https://creativecommons.org/licenses/by/4.0/).

\begin{abstract}
Comparisons to be educative need to happen in a site that belongs to no one. (Radhakrishna, 471). Today comparative literature has expanded its horizons and literary theorists question the very foundation of the word 'compare'. Gayatri Spivak in her essay, Rethinking Comparitivism says that from the very beginning comparative literature did not exactly compare (Spivak, Rethinking 611). A similar view is propounded by R. Radhakrishnan in his essay, Why Compare? where he puts forward his argument that comparisons are unproductive as neither of us learns from the other. He believes that there must be a want to learn from the "others'" experience that is not one's own, instead of persuading the other into believing that one's own "lifeworld" is superior to him (Radhakrishna 454). This paper discusses how these theorists by questioning ethnocentricity, advocating the study of subaltern languages and promoting translation studies aim to foster comparative literature as a dynamic discipline which promotes an objective and ethical thinking amongst the people. It does so by tracing the earliest theoretical concepts and history of Comparative Literature, the challenges it faces and developments advocated by literary critics in the field of comparative literature.
\end{abstract}

Keywords-Comparative Literature, Ethno-centricity, Subaltern Languages, Objectivity.

Comparative literature investigates the relationship between literature and other fields such as history, politics, art and science. It plays a role close to that of studying international relations but mostly deals with languages and artistic practices that aim to understand cultures from within. Placing all of the world literature under a common framework, it aims to examine the features, origins and connection of all literature. Through the study of comparative literature, the total number of works accomplished in the entire world is embraced and is used to demonstrate association, tradition, or influence. We can study the historical starting position of literary phenomena all over the world and examine the affinities in terms of form, structure and ideas closely for similarities and differences in literatures from around the world. The analysis of literature without boundaries gives people a worldly approach to literature. This paper discusses the theoretical concepts and history of Comparative Literature, the challenges it faces and developments advocated by literary critics in the field of comparative literature. It also discusses how these developments advocate an ethical and objective thinking.

The origin of comparative literature can be traced to an inaugural speech at Oxford University in 1857 by Matthew Arnold who coined comparative literature as a translation of literature comparée, saying "No single event, no single literature is properly understood except for other events, to other literature." Then, in 1886 a book Comparative Literature was published by Hutcheon Macaulay Posnett, an Ireland barrister which laid the groundwork in the study of comparative literature. In the year 1901, M. M Posnett wrote an essay called The Science of Comparative Literature in which he gave numerous analyses of this area of study. The subject developed as an autonomous entity at the turn of the nineteenth century and a multi-literary scope to study different languages was created in Europe. Another important contribution in the 
field was by Rene Wellek's challenging address entitled The Crisis of Comparative Literature in which he denounced the French School's emphasis of "'comparative literature' to the study of the foreign trade of two literatures which limits it to a concern with externals" (Wellek 163). He said that unequal power relations between cultures influenced the field due to their literary capital and were measured against the oldest and established ones- the French, the German, the English and other European languages. He sought to research comparative literature as a genre that would transcend all limits of language, ethics and politics. Wellek's opinion that comparative literature was indeed a type of humanism was supported by Rene Etiemble. Today, the earlier world literature that was confined to only the masterpieces of European literature is questioned and challenged. Moreover, a steady migration of academics to the US after the Second World War also led to the growth of comparative literature.

In 1993, Charles Bernheimer issued the American Comparative Literature Association (ACLA) report later published as Comparative Literature in the Age of Multiculturalism (1995). This report described the definitional crisis for a systematic study of such literature, as was discussed earlier by Rene Wellek. It also advocated a rejection of the traditional Eurocentrism and a turn towards global cultural discourses and production. Through the rigorous redefinition, cultural studies, transnational flows, global hegemonies, identity politics, and postcolonial critiques were made inclusive to the study of comparative literature

David Damrosch in his What is World Literature (2003) says "world literature is an elliptical refraction of national literatures " (Damrosch 281). According to him, Goethe's 'weltliterature' marked the end of national literature. The assumption that world literature is limited to a certain region of the world- particularly Europe is now challenged and questioned. With globalisation, works of literature no longer function as single entities in a national context, but exist in a different cultural context, hence developing a new significance for readers across national boundaries. He argues that world literature is a work that "gains in translation" (Damrosh 288).

Charles Bernheimer's work Comparative Literature in the Age of Multiculturalism had advocated the inclusion of subaltern perspectives to comparative literature. Gayatri Spivak in Rethinking Comparativism argues such a development that would "...hope for a sense of equivalence among languages rather than a comparison of historic-civilizational content." (Spivak, Rethinking 612). She proposes that there must be an equivalence of languages and in this equivalence 'comparison in extremis' will not be required in the first place.

'Comparitivism in Extremis' is a term coined by Gayatri Spivak in the esaay. This "comparitivism in extremis" is a kind of a plea to the dominant political other to recognize equivalence and an appeal to end oppression (Rethinking 615). But in this political gesture, a response is denied. Hence, when there is an equivalence of languages, there is no want for the recognition of the dominant. (Spivak, Rethinking 616). It can be said that first that there must a "rethinking of comparitivism...by admitting that languages are equivalent" and in this comparitivism as equivalence, " the comparativists should undertake a serious and continuous undoing of national languages-based reading." (Spivak, Rethinking 613). Spivak argues that, in the U.S, Comparative literature programmes appear to concentrate on the "Europe and the extracurricular Orient" (Spivak, Death 6). She says that the subaltern languages or less-taught languages must be included in the mainstream. For this, she proposes a systematic program of the less taught languages of the world that would include faculty development seminars, post-doctoral fellowships, extensive and new recruitment procedures, development of national professional associations and a consortium of distance language learning (614). Another important development in the field of comparative literature is translation. Today translation is treated as an active rather than prosthetic practice. It acts as the most intimate act of reading and is indispensable for a comparative study.

In an interview, Gayatri Spivak elaborated about her insistence on comparative and language studies. She expresses her belief that language learning enriches the ability to be ethical. In her words,

The way in which an infant acquires language is before reason. In order for this language to be acquired by the infant, the circuits inside the infant that are used - rather than reason, memorizing as it happens when we learn a foreign language - are the same circuits that construct a system that becomes ethical. So, the idea in comparativism, is not just languagelearning but comparativist languagelearning which goes towards literary study - that way of learning-language tries to construct as close as possible a simulacrum to that first language learning remembering that any language can be, in this sense, a first language. In other words, it is a setting 
to action of the metapsychological so that the ethical system can be established (Spivak “Occupy”).

P. Mohanty in his study of objectivity in ethics and aesthetics promotes such study through. In his essay, Can Our Values Be Objective? On Ethics, Aesthetics and Progressive Politics, Mohanty poses the question: "Can we human beings be objective in our views and judgements about properties as goodness, justice or beauty?"(Mohanty 803)

Many postmodern literary and cultural theorists contend that objectivity is unavoidable and impossible. In the debate about human nature between Chomsky and Foucault in the Netherlands in 1971, Chomsky argued that there is an 'innate nature' and identified it with the structures of the human mind whereas Foucault claims that there is no such thing as human nature and even if there is, our understanding of our nature is subjective and inaccurate. P. Mohanty develops on the ideas of Chomsky and believes that values "often refer to deeper features of human nature, our species-wide needs and capacities" and further says that "Our evaluations can be objective, I suggest, because they are often about features of human nature that are independent of our own socially shaped judgments and attitudes"(Mohanty 814).

These assessments show the prejudice and cultural perceptions of our own beliefs. They reflect degrees of error and distortion, as well as accuracy and objectivity. These evaluative norms are not unique and singular objects in the world. As a culture acquires more accurate knowledge of human potentials and capacities, the central evaluative notions and concepts will become richer (Mohanty 814).

Mohanty also argues that even in our evaluation of objectivity analysis are generally ethnocentric. This is more relevant than merely sceptical methods. As Mohanty says,

...since it is overwhelmingly likely that the dominant views about the literary and

aesthetic value in most American universities (to take one example) are for the most

part informed by mainly the Western traditions, discussion of the objectivity of value

will tend to be ethnocentric and ideological even with the best of intentions (829).

According to Mohanty, we must judge social justice not only on our present understanding but on a greater knowledge of the future. Advocating a healthy multicultural society as an ideal laboratory for inquiry about values, he propounds that a comparative epistemic project can be undertaken by studying the relationship between multiculturalism and objectivity. A thoughtfully planned, team-taught course on comparative aesthetics may, in fact, help make students (and their teachers) less smug about their cultural categories and more open to an objective assessment of the difficulty of particular judgments about aesthetic value. (Mohanty 829). And to ensure that objectivity ceases to be ethnocentric, he says that every course on aesthetic values must be prepared in a way where the "primary emphasis is comparative and crosscultural."(Mohanty 829). Such courses will make students more objective in their assessment of particular judgements.

Jonathan Culler in his Wither Comparative literature says that comparative literature has today in a way successfully accomplished its idea of focusing on addressing theoretical issues and importing and exploring 'foreign' theoretical discourses.

Even the study of American literature, once committed to exceptionalism and totalization (Americanists had to have a theory about the nature and distinctiveness of American literature), is now in the process of reconfiguring itself as 'comparative American literatures,' in the plural. Culler argues that though treating literature "one discourse among others" has been valuable considering the comparatists' contribution to study of philosophical, psychoanalytical, political and other discourses, this "going global and going cultural" is an overwhelming scope and seems impossible to be an academic discipline at all (87).

If one were creating a university from scratch, one could doubtless construct a large department of comparative literature charged with global cultural studies, but then the question of differential identity raises its head: would there be any other departments in the humanities to contrast with comparative literature? Would there be a need for music, art, literature, and philosophy departments, or departments to study different areas of the world, or would comparative literature in this new dispensation cover everything in the humanities and much of the social sciences? (Culler 87)

One model Culler suggests for addressing this is Erich Auerbach's conception of the Ansatzpunkt. He defines Ansatzpunkt. as a handle, as it were, by which the subject can be seized. The point of departure must be the election of a firmly circumscribed, easily comprehensible set of phenomena whose interpretation is radiation out from them and which orders and interprets a greater region than they themselves occupy (Auerbach 14). This model enables the 
critic to bring together a variety of cultural objects (Culler 93).

Radhakrishnan in Why Compare also propounds a similar view saying that centrism functions like the concept of a family but at the same time questions: "Is it possible to cultivate one's location a-centrically, pluri-centrically or eccentrically?"(Radhakrishna 463). It is important to initiate the comparison by starting at one position and not declare it as the centre. There must be a rigorous effort to autocritique and auto defamiliarize in response to the presence of the other.

Spivak's insistence on language learning and Mohanty's belief that the study of a multi-cultural society will lead to an objective and ethical behaviour among varied cultures and society is similar to what Radhakrishna also puts forward. He also says that the emphasis on the study of languages and the study of multiculturalism in universities will help us to "recognise our differences from each other and then wonder what to do with or how to negotiate this difference"(Radhakrishna 460). He says that when instructing their students on writing a paper that compares two works, professors tell the students to ensure that they delineate the grounds of comparison. Emphasizing the word epistemological as a comparative project desires a new knowledge and such comparison must be more progressive, worldly and cosmopolitan. He says that when comparing "the two works to be compared are deterritorialized from their original 'milieu' and reterritorialized so that they do not occupy the same space"(Radhakrishnan 456). It may be said that only when a comparison does not occupy the same space and happen at a site that belongs to no one, can they be educative.

Radhakrishnan repudiates that need for comparison. He says that we must honour the world as one and also accept its heterogeneity. He also discusses his envisioned affirmative future projects of fusion and hybridity. Discussing the conversation between his auto driver in Chennai and himself when he returns to India, he comments that their conversation is mostly centred on the traffic in Chennai and US. To the auto driver, the orderly lane system is US is appalling as it restricts the driver's creativity, and if followed it may not allow the autos to maintain its dominance over other cars (Radhakrishnan 453). After trying to convince him, Radhakrishnan abandons the very possibility of a comparativists epistemology. Recommending a similar approach to comparative literature, Radhakrishnan emphasizes that we must give up this ethical dilemma of persuading the other into believing that one's own 'lifeworld' is superior to him (Radhakrishnan 453).
Comparisons, he says, can never be disinterested or neutral. They are always tendentious and competitive and willed into existence by a will to power/ knowledge. He rightly says that if neither of us learns from the other, comparisons prove to be unproductive. "There should be a want to learn from 'other' experience that is not one's own rather than to hierarchize difference in name of a dominant 'superior' identity" (Radhakrishnan 455). When comparisons are made, we need to look at who is making the comparison, who is at stake in the comparison and who will benefit from this comparison. He questions "Why the Eastern and the Western self, the colonizer self and the colonized self, cannot disinvest from their present history of binary recognition and invest their common accountability" (Radhakrishnan 465) to the what is ethically correct. This learning from the binary other must happen at another wavelength, and not on the theme of comparison. He also discusses that in the field of philology and translation studies, there is a conventional tendency of talking about the families of language as Indo-European, Semitic, Slavic by investigating the proximity and distance between them (467). Though these are two different languages, despite their differences, they partake in a common familial self or identity. He says that unless comparisons bring into existence the other 'we', it loses its salience. There is an inescapable bind- we must compare and yet be careful of not committing epistemic violence. In the words of Radhakrishnan,
The double bind of comparison works thus: on the one hand, a comparative methodology has to persuade each of the entities implicated in the comparison to reidentify itself concerning the other; and on the other hand, it has an obligation to "let each entity be"(Radhakrishnan 461).

Also, he questions that how can equal comparisons be made in an unequal world - it is what haunts comparativism as he says 'apples and oranges' cannot be compared, yet if new knowledge is to be added then they need to be compared. He compares feministic critics Andrienne Rich and Virginia Woolf with C. S Laxmi saying that although they are from different historical periods and location, they share a mutual relation to one another as they have comparable articulations of gender, ecriture, gynocentric and androcentric divide. Hence where they come from turns into a mere empirical detail and can be explained by a meaningful theoretical enterprise (Radhakrishnan 457). 


\section{CONCLUSION}

The developments as expounded by Mohanty, Spivak and Radhakrishnan in the field of comparative literature question ethnocentricity, promote the study of subaltern languages and translation studies enhancing the field of comparative literature, and also discusses how such a study facilitates an objective and ethical thinking. To be defined as ethical, one has to question if one's judgements are guided by one's political preferences or cultural and social experiences as propounded by Mohanty (Can Our). Where Gayatri Spivak believes that trying to discover varieties of sameness is a false promise of a level playing field (Rethinking), Radhakrishnan proposes that the two must constitute a "we". But that "we" is to be located across differences of location, profession and class (Why Compare?). Discovering similarities in diverse cultures and languages is a nuanced paradigm but at the same time, a need for "we-ness" is also important. In this ethical dilemma, I suggest that we must thus compare at a site that belongs to no one, as suggested by Radhakrishnan. Also, as is put forward by these literary theorists, this unbiased and non-ethnocentric approach can be achieved through a study of literature in a healthy multi-cultural society and there must be common accountability to the Big $\mathrm{O}$ that defines the judgements of one's behaviour in relation to 'what ought to be' and 'what should be' ethical (Radhakrishnan 465).

\section{REFERENCES}

[1] Arnold, Matthew. " On the Modern Elements in Literature". University of Oxford, 14 Nov. 1857. Lecture.

[2] Auerbach, Erich, et al. "Philology and Weltliterature."' The Centennial Review, vol. 13, no. 1, 1969, pp. 1-17. JSTOR, www.jstor.org/stable/23738133

[3] Bernheimer, Charles. Comparative Literature in the Age of Multiculturalism. Johns Hopkins University Press, 1995

[4] Culler, Jonathan D. "Whither Comparative Literature." Comparative Critical Studies, vol. 3 no. 1, 2006, pp. 85-97. Project MUSE, doi:10.1353/ccs.2006.0005

[5] Damrosch, D. What Is World Literature? Princeton University Press, 2003.

[6] ---., et al., editors. "The Crisis of Comparative Literature." The Princeton Sourcebook in Comparative Literature: From the European Enlightenment to the Global Present, Princeton UP, 2009, pp. 161-172.

[7] Mohanty, Satya P. (Satya Prakash). "Can Our Values Be Objective? On Ethics, Aesthetics, and Progressive Politics." New Literary History, vol. 32 no. 4, 2001, pp. 803-833. Project MUSE, doi:10.1353/nlh.2001.0055E

[8] Radhakrishnan, R. "Why Compare?". New Literary History, vol. 40, no. 3, Summer 2009, pp. 453471,ww.jstor.org/stable/27760271

[9] Spivak, Gayatri Chakravorty. "Rethinking Comparativism." New Literary History, vol. 40, no. 3, Summer 2009, doi: 10.1353/nlh.0.0095
[10] ---."Death of a Discipline." Columbia University Press, 2003. JSTOR, www.jstor.org/stable/10.7312/spiv129440.

[11] ---. Interview by Rahul K. Goirala. Occupy Education: An Interview with Gayatri Chakravorty Spivak.25 Sep. 2012. https://politicsandculture.org/2012/09/25/occupyeducation-an-interview-with-gayatri-chakravorty-spivak. Accessed 20 May 2019. 